\title{
Optimization of a Ship Turning Basin Using Real Time Simulations - A Case Study for the Quai Des Trois Fontaines (Chooz, France)
}

\author{
M. Mansuy \& M. Candries \\ Ghent University, Ghent, Belgium \\ K. Eloot \\ Flanders Hydraulics Research, Antwerp, Belgium \\ B. Wéry \\ IMDC, Antwerp, Belgium
}

\begin{abstract}
The Quai des Trois Fontaines is a berthing area in Chooz, France, which was designed for $80 \mathrm{~m}$ long vessels (CEMT Class IV) plying the River Meuse. A turning basin is located in front of the Quai des Trois Fontaines to allow vessels to turn before loading at the quay. Real time simulations on a dedicated inland ship manoeuvring simulator at Flanders Hydraulics Research were carried out with experienced skippers to study how the safety of the turning manoeuvre could be improved and which measures are required for safe manoeuvres with longer vessels, i.e. vessels of 85 and $90 \mathrm{~m}$ in length.

In the first phase of the study, turning manoeuvres of CEMT Class IV vessels of $80 \mathrm{~m}, 85 \mathrm{~m}$ and $90 \mathrm{~m}$ long were studied in the existing environment. The manoeuvres were evaluated based on different safety criteria and on the feedback of the pilots. The real time simulations have shown that the actual design of the turning basin is suitable for the $80 \mathrm{~m}$ long vessels in any hydro-meteorological condition. However, the manoeuvres become risky with $85 \mathrm{~m}$ long vessels under certain conditions and impossible with longer ships. Although the current can be very strong on the river Meuse, the local width turned out to be the most critical parameter.

In the second phase of the study, measures were proposed to allow the safe turning of $85 \mathrm{~m}$ and $90 \mathrm{~m}$ long vessels. Local widening of the river to $100 \mathrm{~m}$ and to $105 \mathrm{~m}$ were proposed for $85 \mathrm{~m}$ and $90 \mathrm{~m}$ long ships respectively. A third proposed measure is to provide a fixed point near the end of the quay, to which the vessels can attach and around which they can then turn.
\end{abstract}

\section{INTRODUCTION}

The Quai des Trois Fontaines is a berthing area near the town of Givet in the Ardennes region of France, which was designed for $80 \mathrm{~m}$ long vessels (CEMT Class IV) plying the River Meuse. A turning basin is located in front of the Quai des Trois Fontaines to allow vessels to turn before loading at the quay, as indicated in Figure 1.

The quay is hardly used at present. Strong currents can be present in this area and some skippers do not feel confident about the safety of the turn, especially because there is a shallow zone present on the right bank (see Figure 1). In addition, it is thought by the local authorities that more traffic would be generated if the quay would be able to receive larger vessels [1].

A study was therefore commissioned by the waterway authority, Voies Navigables de France, to study how the safety of the turning manoeuvre could be improved and which measures are required for safe manoeuvres with larger vessels, i.e. vessels of 85 and $90 \mathrm{~m}$ in length. To this end, the environment of the Quai des Trois Fontaines was modelled in a dedicated inland ship manoeuvring simulator and real time simulations were carried out with experienced skippers. 


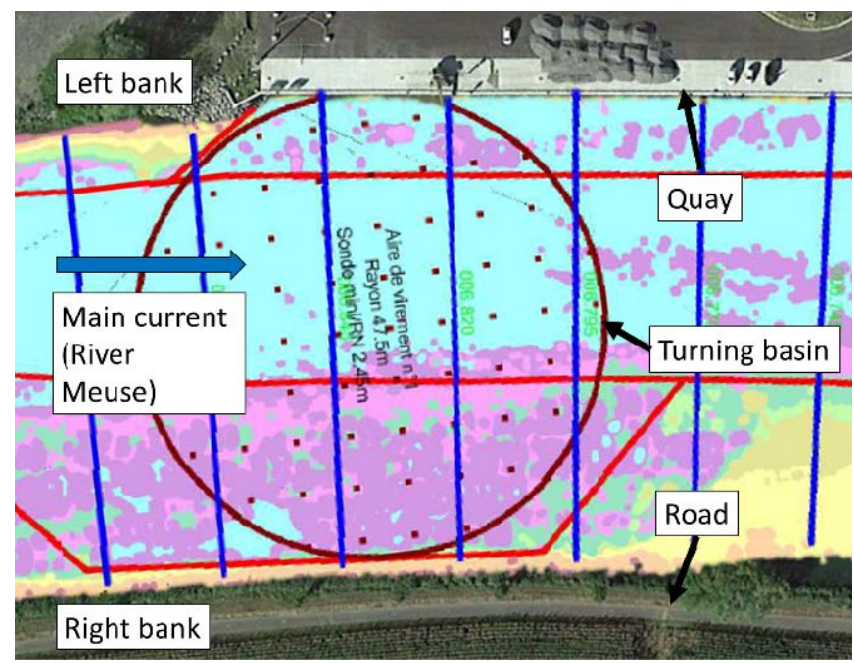

Figure 1. Turning basin geometry near the Quai des Trois Fontaines in Chooz (France).

Table 1. Lengths of turning basins as a factor of ship dimension from existing guidelines [2]

\begin{tabular}{lll}
\hline & River & Canal \\
\hline China & $2.5 \mathrm{~L}(4.0 \mathrm{~L})^{*}$ & $2.0 \mathrm{~L}$ \\
Dutch & case by case & $1.2 \mathrm{~L}$ \\
Germany & case by case & $1.2 \mathrm{~L}$ \\
US & $1.5 \mathrm{~L}^{* *}$ & $1.2-1.5 \mathrm{~L}^{* *}$ \\
PIANC [2] & $1.5 \mathrm{~L}$ & $1.2 \mathrm{~L}$ \\
\hline
\end{tabular}

* V Flow $>1.5 \mathrm{~m} / \mathrm{s}$

${ }^{* *}$ For maritime ports and $V_{\text {Flow }}<0.8 \mathrm{~m} / \mathrm{s}$

With a diameter of $95 \mathrm{~m}$ for $80 \mathrm{~m}$ long vessels, the turning basin almost complies with 1.2. $\mathrm{L}$ as described by the design guidelines for free turning manoeuvres [2]. Strictly speaking, however, the turning basin does not comply with any of the guidelines, as indicated in Table 1. Because of safety reasons and to allow for an easy turn without being forced to use additional thrusters, the guidelines indicate that a turning diameter should be larger than L [2].

In severe hydro-meteorological conditions, a fixed point (i.e. a dolphin) to which the ship can attach and around which it can then turn, can also be used to reduce the required width of the turning basin. However, a disadvantage is the necessary length of the semi-circular turning area, which should be at least $2 \cdot \mathrm{L}$, with some extra allowance in case mooring lines are used [2].

In case of free-flowing rivers, high currents can cause drift and sedimentation, which are major issues and deserve particular attention when designing turning basins. In reality, due to environmental, economic or geotechnical restrictions, the recommended dimensions can often not be met. In those cases, real time simulations become a useful tool to determine less conservative designs, which are more adapted to the actual situation. The use of manoeuvring simulations to study the detailed design of a turning basin is an established practice and several examples can be found in literature, e.g. [3-7].

This paper illustrates the use of real time simulations to optimize the existing turning basin located at the Quai des Trois Fontaines in Chooz (France) and to make it accessible to larger vessels. Section 2 explains how these real time simulations were set up and which criteria are used to evaluate the manoeuvres. Section 3 discusses the simulations that were carried out in the environment as it exists today, whereas Section 4 discusses the simulations that were carried out in an environment which was modified in order to be able to turn with vessels that are $85 \mathrm{~m}$ and $90 \mathrm{~m}$ long. In Section 5, finally, the conclusions are given.

\section{MANOEUVRABILITY ASSESSMENT}

\subsection{Manoeuvring simulator}

About 70 free and fixed turning manoeuvers were simulated on a full mission manoeuvring simulator at Flanders Hydraulics Research, which has been specially developed for inland navigation research. The inland navigation simulator is composed of a bridge with $210^{\circ}$ aerial view displayed on 52" LCD monitors, as shown in Figure 2. The bridge is equipped with:

- ECDIS and radar

- Controllable camera views

- Controllable bridge height

- Vertical view down for manoeuvres close to a lock or a wall

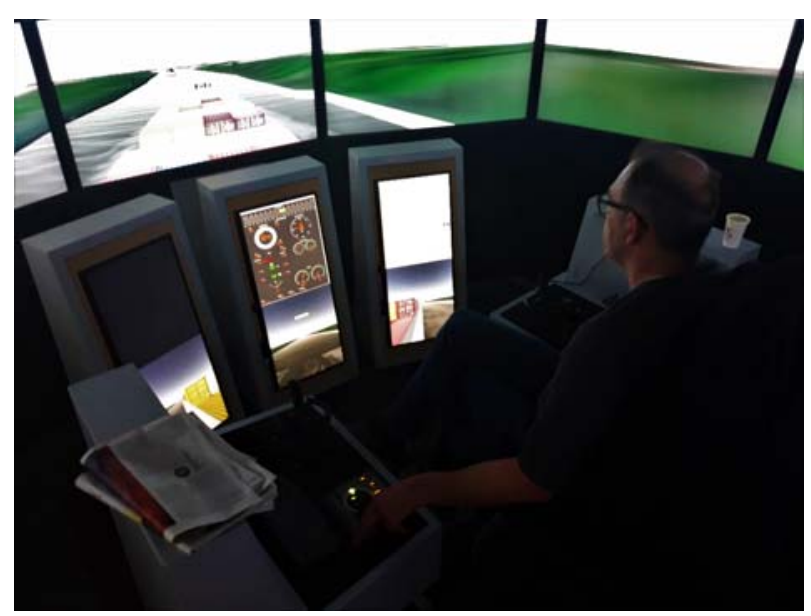

Figure 2. Manoeuvring simulator for inland navigation (Flanders Hydraulics Research, Belgium).

\subsection{Ship models}

Extensive model testing has been carried out with a scale model of a class Va (110m of full scale length) in the Towing Tank for Confined Water at Flanders Hydraulics Research to provide data for the mathematical manoeuvring models at different drafts and underkeel clearances (10 to $100 \%$ of the draft) [7]. By scaling from model to different full scale classes of inland vessels (between class IV with $85 \mathrm{~m}$ length and class $\mathrm{Va}$ ) the mathematical models could be used to evaluate the manoeuvring behaviour of inland navigation vessels in design cases such as the Quai des Trois Fontaines. Based on fast time simulations with the derived class IV and class Va vessel types at interpolated conditions for the draft and the under keel clearance, the mathematical models were validated in [8] based on measurements on real vessels in Flemish waterways. For the present study, 
two new models were derived for class IV vessels with a length of $80 \mathrm{~m}$ and $90 \mathrm{~m}$ from the existing $85 \mathrm{~m}$ long model. The mathematical models also take bank effects into account and have the option to include a bow thruster, the use of which can be restricted depending on the simulation scenario.

\subsection{Evaluation criteria}

Different criteria are used to evaluate the difficulty and safety of the manoeuvres. The most critical parameter is the distance between the ship and the depth line corresponding to the draft of the vessel, which is either $1.7 \mathrm{~m}$ or $2.5 \mathrm{~m}$.

Three other parameters that are used as criteria, are the reserve of the propeller, the reserve of the bow thruster and the reserve of the rudder. In general, the reserve of a control parameter $n$ represents the reserve that is available in case a problem occurs and is defined by the following formulation:

$$
R_{n}=1-\frac{\hat{n}}{n_{\max }}
$$

with:

$R_{n}$ : Reserve of the control parameter $\mathrm{n}$

$\hat{n}^{n}$ : Mean value of the parameter $n$

$n_{\text {max }}$ : Maximum value of the parameter $\mathrm{n}$

For the three criteria mentioned above, the control parameter $\mathrm{n}$ is equal to the number of revolutions of the main propeller, the number of revolutions of the bow thruster and the rudder angle respectively.

The manoeuvrability of the ship can then easily be evaluated based on the criteria using a colour code. Table 2 indicates for which values for each of the parameters a colour changes. A manoeuvre is unacceptable whenever at least one of the criteria turns red.

Table 2. Safety criteria.

\begin{tabular}{lcccc}
\hline $\begin{array}{l}\text { Reserve } \\
\text { main } \\
\text { propeller }\end{array}$ & $\begin{array}{l}\text { Reserve } \\
\text { bow } \\
\text { thruster }\end{array}$ & $\begin{array}{l}\text { Reserve } \\
\text { rudder }\end{array}$ & $\begin{array}{l}\text { Min. } \\
\text { distance } \\
\text { to isolines }\end{array}$ \\
\hline Inacceptable & $<10 \%$ & $<10 \%$ & $<10 \%$ & $<10 \%$ \\
Acceptable & $10 \%-25 \%$ & $<30 \%$ & $<50 \%$ & $<50 \%$ \\
No constraints & $>50 \%$ & $<100 \%$ & $50 \%-70 \%$ & $<100 \%$ \\
\hline
\end{tabular}

\subsection{Skippers}

The real time simulations in this study were executed by professional skippers who have ample experience both with class IV vessels and with the navigation area.

After each simulation a debriefing session was organized, during which the skipper could give his opinion about the simulation and the manoeuvres that were performed. The difficulty as well as the safety of the manoeuvre is rated on a scale from 1 to 6 . This feedback adds relevant information to the analysis considered along with the safety criteria when a manoeuvre is evaluated.

\subsection{Hydraulic conditions}

The current flow was implemented using a 3D hydraulic model developed by IMDC (International Marine and Dredging Consultants). Different hydraulic conditions were modelled based on representative flow rates measured upstream. An overview of the simulated conditions is given in Table 3 from low water flow to the maximum operational conditions.

Table 3. Hydraulic conditions

\begin{tabular}{llll}
\hline Cond. & $\begin{array}{l}\text { Flow } \\
\text { rate } \\
\left(\mathrm{m}^{3} / \mathrm{s}\right)\end{array}$ & $\begin{array}{l}\text { Mean } \\
\text { current speed } \\
(\mathrm{m} / \mathrm{s})\end{array}$ & $\begin{array}{l}\text { Waterlevel } \\
\text { upstream } \\
(\mathrm{m} \text { NGF })\end{array}$ \\
\hline Q min & 29.0 & 0.16 & $99.55(\min )$ \\
Q med. & 87.4 & 0.36 & $99.65($ Normal) \\
Q 60\% & 114 & 0.4 & $99.75(\max )$ \\
Q 75\% & 177 & 0.6 & $99.75(\max )$ \\
Q 90\% & 310 & 0.85 & $99.75(\max )$ \\
Q Max & 400 & 1.1 & $99.75(\max )$ \\
\hline
\end{tabular}

\section{EXISTING ENVIRONMENT - EVALUATION OF TURNING MANOEUVRES CARRIED OUT WITH CEMT CLASS IV VESSELS}

\section{1 $80 \mathrm{~m}$ Long vessels}

The turning manoeuvre near the Quai des Trois Fontaines was first simulated with a $80 \mathrm{~m}$ long ship with a draft of $1.7 \mathrm{~m}$, representative of an empty ship. The manoeuvres were evaluated to be safe, but with relatively low safety margins at the highest flow rate, as indicated for one simulation in Table 4 and Figure 3. Overall, the analysis indicates that the turning basin is well designed for $80 \mathrm{~m}$ long vessels with a draft of $1.7 \mathrm{~m}$. Pilots can be confident when turning with empty vessels in this area as the underkeel clearance is sufficient at all times.

Table 4. Manoeuvrability assessment, free turn of an $80 \mathrm{~m}$ long vessel.

\begin{tabular}{|c|c|c|c|c|c|}
\hline Distances & \multicolumn{2}{|c|}{ Reserve overview } & \multicolumn{2}{c|}{ Pilot feedback } \\
\hline $\begin{array}{c}\text { Min dist } \\
1.7 \mathrm{~m}[\mathrm{~m}]\end{array}$ & $\begin{array}{c}\text { Main } \\
\text { propeller }\end{array}$ & $\begin{array}{c}\text { Bow } \\
\text { thruster }\end{array}$ & Rudder & Reserve & Difficulty \\
\hline \multicolumn{5}{|c|}{ Q $90 \%\left(310 \mathrm{~m}^{3} / \mathrm{s}\right)$} & $/ 6$ \\
\hline 5.5 & $64 \%$ & $64 \%$ & $69 \%$ & 3 & 3 \\
\hline
\end{tabular}

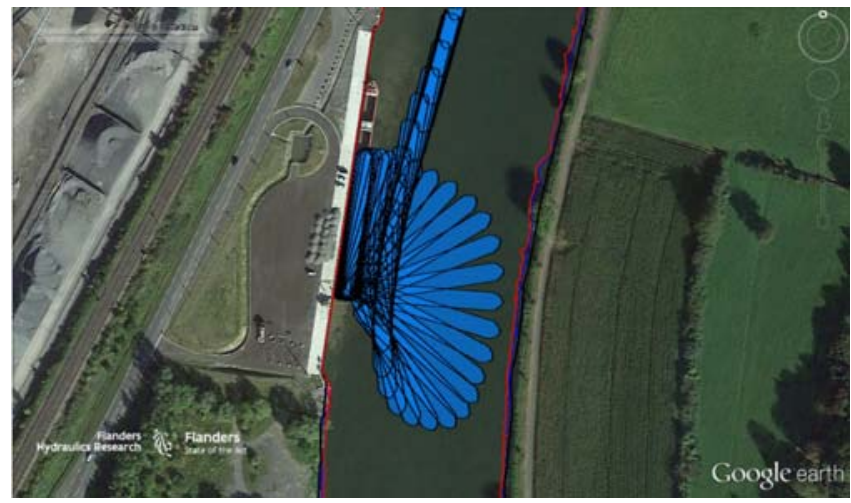

Figure 3. Plot of the trajectory with an $80 \mathrm{~m}$ long vessel with a draft of $1.7 \mathrm{~m}$, turning freely with Q90\%. 


\section{$3.285 \mathrm{~m}$ Long vessels}

The manoeuvres become more difficult with a ship of $85 \mathrm{~m}$ long. As indicated in Table 5, the manoeuvres are only acceptable below Q75\%. There is enough space available in the longitudinal direction to accommodate the drift motion of the ship that occurs due to wind and current. However, the width of the river is too restricted. When the ship is aligned with the river, the skipper is counteracting the longitudinal current/wind forces, which are directed against the heading of the ship. When the ship is then turning, these wind/current forces come from the side and the skipper needs to adjust the controls quickly to counteract the lateral forces in time. However, the reaction of the vessel takes some time and the force equilibrium is broken for a while. As a result, the skipper does not manage to keep a safe distance from the banks, as indicated for one simulation in Figure 4. The analysis indicates that a larger safety margin is required. In addition, the simulations show that the use of bow thruster is necessary during the turning manoeuvre, as indicated by Figure 5 . Without bow thruster, the turning manoeuvre takes too long, the vessel is too difficult to control under the imposed environmental circumstances and it comes too close to the right bank.

Table 5. Manoeuvrability assessment, free turn of an $85 \mathrm{~m}$ long vessel.

\begin{tabular}{|c|c|c|c|c|c|}
\hline \multirow{2}{*}{$\begin{array}{r}\text { Distances } \\
\text { Min dist } \\
1.7 \mathrm{~m}[\mathrm{~m}]\end{array}$} & \multicolumn{3}{|c|}{ Reserve overview } & \multicolumn{2}{|c|}{ Pilot feedback } \\
\hline & $\begin{array}{c}\text { Main } \\
\text { propeller }\end{array}$ & $\begin{array}{c}\text { Bow } \\
\text { thruster }\end{array}$ & Rudder & $\begin{array}{c}\text { Reserve } \\
/ 6\end{array}$ & $\begin{array}{c}\text { Difficulty } \\
/ 6\end{array}$ \\
\hline \multicolumn{6}{|c|}{$\mathrm{Q} \min \left(29 \mathrm{~m}^{3} / \mathrm{s}\right)$} \\
\hline 3.5 & $68 \%$ & $69 \%$ & $63 \%$ & 3 & 3 \\
\hline \multicolumn{6}{|c|}{ Q med $\left(87.4 \mathrm{~m}^{3} / \mathrm{s}\right)$} \\
\hline 1.8 & $75 \%$ & $78 \%$ & $72 \%$ & 3 & 3 \\
\hline \multicolumn{6}{|c|}{ Q 60\% $\left(114 \mathrm{~m}^{3} / \mathrm{s}\right)$} \\
\hline 2.9 & $61 \%$ & $68 \%$ & $68 \%$ & 2 & 2 \\
\hline \multicolumn{6}{|c|}{ Q 75\% $\left(177 \mathrm{~m}^{3} / \mathrm{s}\right)$} \\
\hline 0 & $73 \%$ & $87 \%$ & $67 \%$ & 5 & 6 \\
\hline \multicolumn{6}{|c|}{ Q $90 \%\left(310 \mathrm{~m}^{3} / \mathrm{s}\right)$} \\
\hline 0 & $42 \%$ & $29 \%$ & $40 \%$ & 5 & 6 \\
\hline
\end{tabular}
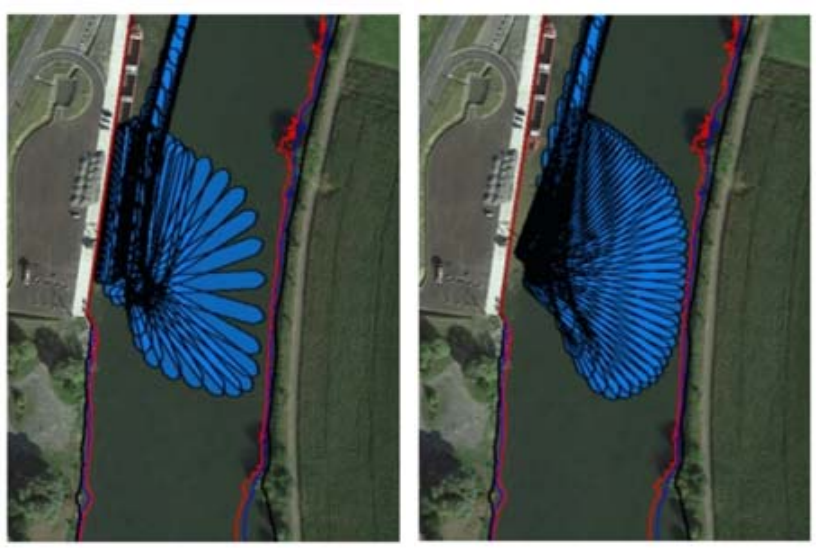

(a)

(b)

Figure 4. Free turn of an $85 \mathrm{~m}$ long vessel executed with (a) and without (b) bow thruster.

\section{3 $90 \mathrm{~m}$ Long vessels}

When the manoeuvre is carried out with a $90 \mathrm{~m}$ long ship, the skipper is unable to complete the manoeuvre without touching a bank. The river is simply not wide enough to carry out the manoeuvre, as indicated in Table 6.

Table 6. Manoeuvrability assessment, free turn of a $90 \mathrm{~m}$ long vessel.

\begin{tabular}{|c|c|c|c|c|c|}
\hline Distances & \multicolumn{2}{|c|}{ Reserve overview } & \multicolumn{2}{c|}{ Pilot feedback } \\
\hline $\begin{array}{c}\text { Min dist } \\
1.7 \mathrm{~m}[\mathrm{~m}]\end{array}$ & $\begin{array}{c}\text { Main } \\
\text { propeller }\end{array}$ & $\begin{array}{c}\text { Bow } \\
\text { thruster }\end{array}$ & Rudder & $\begin{array}{c}\text { Reserve } \\
/ 6\end{array}$ & $\begin{array}{c}\text { Difficulty } \\
/ 6\end{array}$ \\
\hline \multicolumn{6}{|c|}{ Q $\min \left(29 \mathrm{~m}^{3} / \mathrm{s}\right)$} \\
\hline 0 & $78 \%$ & $84 \%$ & $65 \%$ & 5 & 4 \\
\hline \multicolumn{6}{|c|}{ Q med $\left(87.4 \mathrm{~m}^{3} / \mathrm{s}\right)$} \\
\hline 0 & $79 \%$ & $72 \%$ & $60 \%$ & 5 & 4 \\
\hline \multicolumn{6}{|c|}{ Q $60 \%\left(114 \mathrm{~m}^{3} / \mathrm{s}\right)$} \\
\hline 0 & $73 \%$ & $70 \%$ & $54 \%$ & 5 & 4 \\
\hline \multicolumn{6}{|c|}{ Q 75\% $\left(177 \mathrm{~m}^{3} / \mathrm{s}\right)$} \\
\hline 0 & $67 \%$ & $68 \%$ & $59 \%$ & 5 & 5 \\
\hline
\end{tabular}

\section{MEASURES TO OPTIMIZE THE DESIGN OF THE TURNING BASIN}

The next stage in the study was to propose measures which would allow the safe turning of $85 \mathrm{~m}$ and $90 \mathrm{~m}$ long vessels.

From the analysis of the simulations executed in the actual existing environment, it was concluded that the width of the river at the location of the turning basin was the most critical parameter. Therefore two new designs were proposed, enlarging the width of the river to $100 \mathrm{~m}$ and $105 \mathrm{~m}$ to allow the turning of an $85 \mathrm{~m}$ long and $90 \mathrm{~m}$ long vessel respectively, as indicated in Figure 7 . These widths were proposed based on the superposition of the envelope of the ships' trajectories obtained from the simulations in the existing environment, cf. Section 3.

A third option that was proposed, is to use a fixed point at the end of the Quai des Trois Fontaines to which the vessel can attach with a rope and around which it can then turn. This fixed point, that is placed in the original environment and studied separately from the previous two options, is in effect a dolphin around which the ship can turn, as shown in Figure 8. 

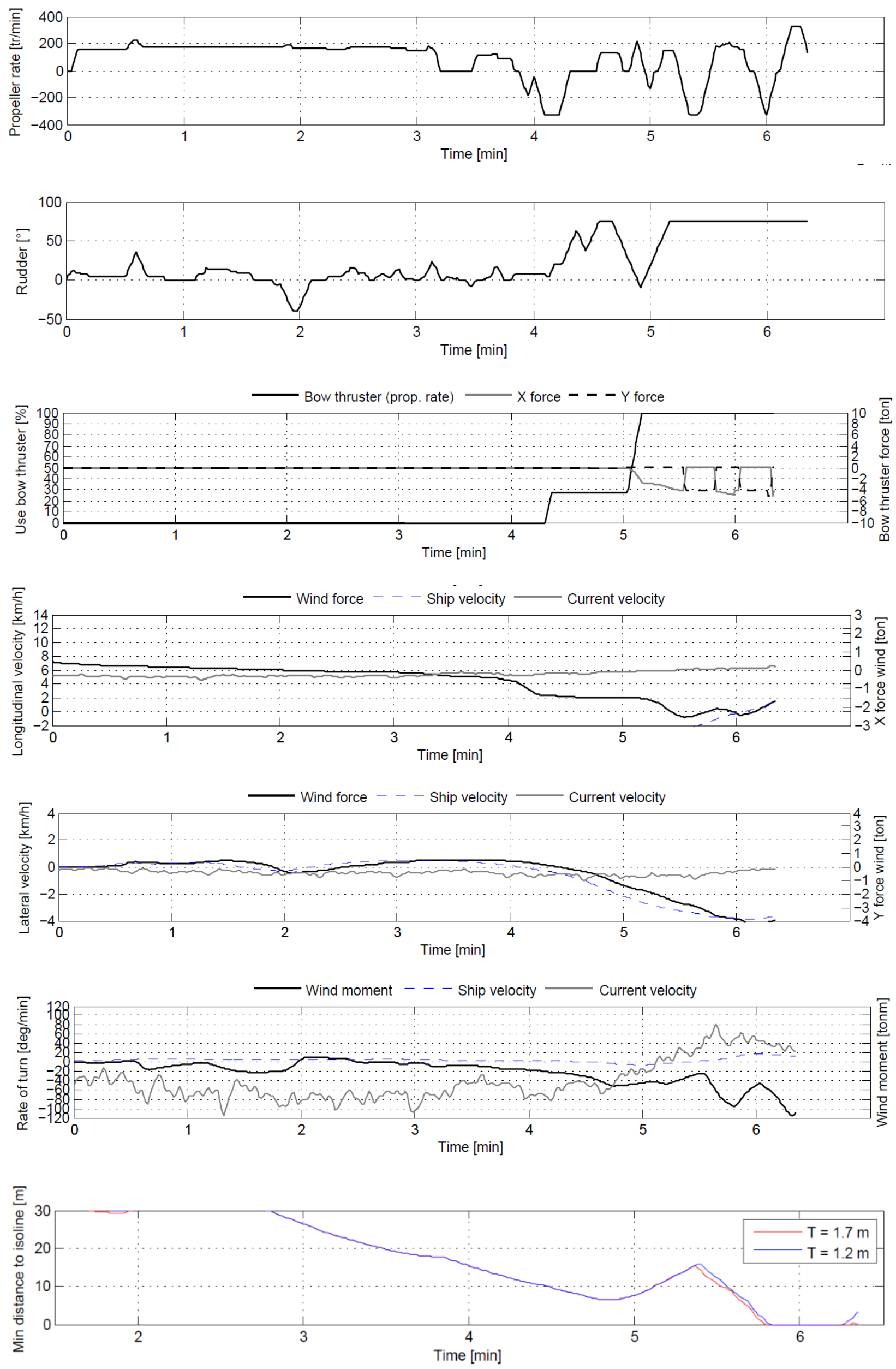

Figure 5. Time series of an $85 \mathrm{~m}$ long vessel turning freely with Q90\%. 


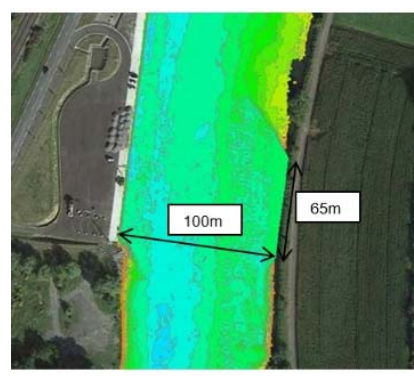

(a)

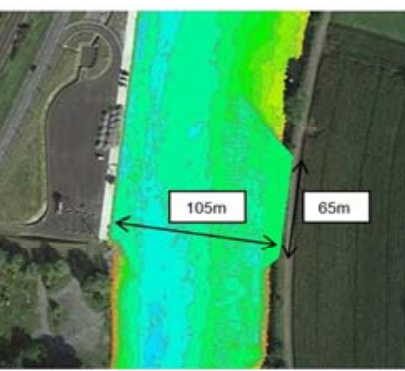

(b)

Figure 7. Proposed widening of the river in order to improve the turning conditions for $85 \mathrm{~m}$ long (a) and $90 \mathrm{~m}$ long vessels (b).

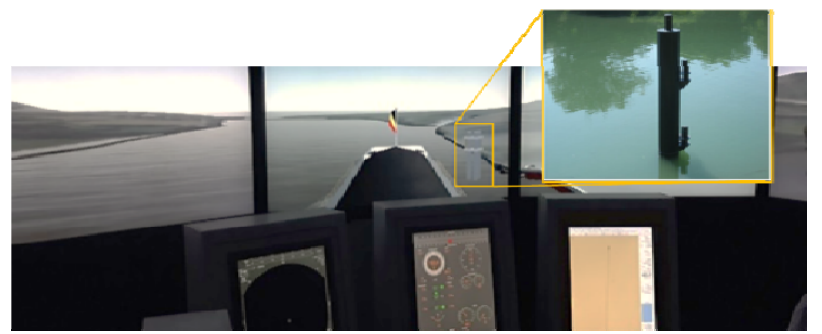

Figure 8. Fixed point (dolphin) implemented in the simulator to improve the turning conditions.

\section{$4.185 \mathrm{~m}$ long vessels}

The simulations showed that there were no problems when the river was widened by $5 \mathrm{~m}$ to a total width of $100 \mathrm{~m}$ at the turning location.

Different positions were studied for the fixed point (dolphin) around which the ship could turn best. Based on the simulations results and the feedback of the skippers, a position on the left bank seemed more appropriate. Consequently, safe manoeuvres were successfully executed with a $85 \mathrm{~m}$ long vessel turning around this point, as shown in Table 7 and Figure 9.

Table 7. Manoeuvrability assessment, $85 \mathrm{~m}$ long vessel, actual turning basin, but with a fixed point on the left bank to which the vessel can attach and around which the vessel can then turn.

\begin{tabular}{|c|c|c|c|c|c|}
\hline Distances & \multicolumn{3}{|c|}{ Reserve overview } & \multicolumn{2}{c|}{ Pilot feedback } \\
\hline $\begin{array}{c}\text { Min dist } \\
1.7 \mathrm{~m}[\mathrm{~m}]\end{array}$ & $\begin{array}{c}\text { Main } \\
\text { propeller }\end{array}$ & $\begin{array}{c}\text { Bow } \\
\text { thruster }\end{array}$ & Rudder & $\begin{array}{c}\text { Reserve } \\
/ 6\end{array}$ & $\begin{array}{c}\text { Difficulty } \\
/ 6\end{array}$ \\
\hline \multicolumn{5}{|c|}{ Q 90\% $\left(310 \mathrm{~m}^{3} / \mathrm{s}\right)$} \\
\hline 4 & $65 \%$ & $72 \%$ & $72 \%$ & 3 & 3 \\
\hline
\end{tabular}

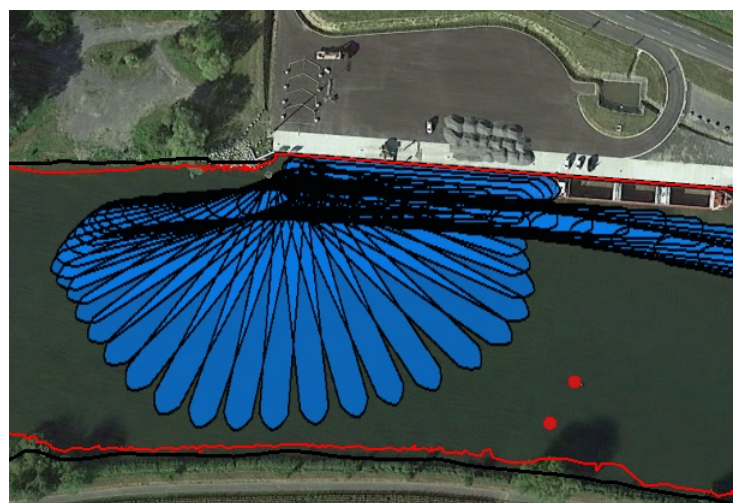

Figure 9. Track of an $85 \mathrm{~m}$ vessel, actual basin with a fixed point on the left bank.

\section{$4.290 \mathrm{~m}$ Long vessels}

The simulations showed that widening the river by 10 $\mathrm{m}$ to a total width of $105 \mathrm{~m}$ over a length of $65 \mathrm{~m}$ was not sufficient for the safe turning of a $90 \mathrm{~m}$ long vessel. As indicated in Figure 10, the dowstream part of the turning basin should be widened as well. The presence of rocks at this location would make this measure rather expensive.

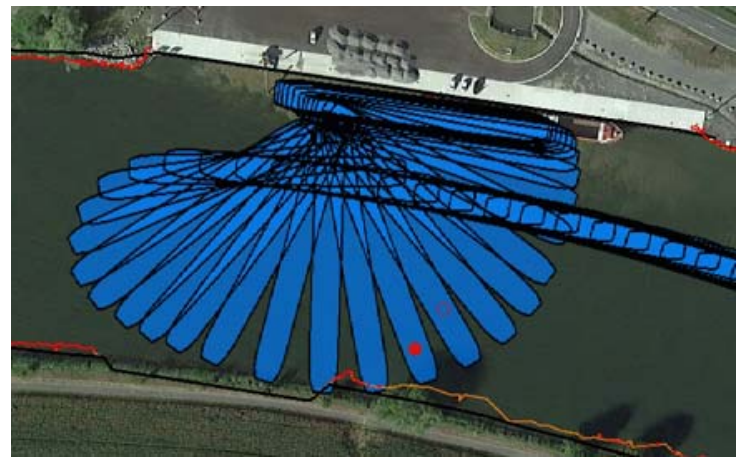

Figure 10. Track of a $90 \mathrm{~m}$ vessel, widening of $105 \mathrm{~m}$.

When a fixed point is provided around which the vessel can turn, the distance to the bank is better controlled. Safe manoeuvres can be carried out without widening the river locally, but the distance from the right bank during the turning manoeuvre becomes quite small, as indicated in Table 8 .

Table 8. Manoeuvrability assessment, free turn of a $90 \mathrm{~m}$ long vessel, actual basin, with a fixed point on the left bank.

\begin{tabular}{|c|c|c|c|c|c|}
\hline Distances & \multicolumn{3}{|c|}{ Reserve overview } & \multicolumn{2}{c|}{ Pilot feedback } \\
\hline $\begin{array}{c}\text { Min dist } \\
1.7 \mathrm{~m}[\mathrm{~m}]\end{array}$ & $\begin{array}{c}\text { Main } \\
\text { propeller }\end{array}$ & $\begin{array}{c}\text { Bow } \\
\text { thruster }\end{array}$ & Rudder & $\begin{array}{c}\text { Reserve } \\
/ 6\end{array}$ & $\begin{array}{c}\text { Difficulty } \\
/ 6\end{array}$ \\
\hline \multicolumn{5}{|c|}{$\mathrm{Q} 90 \%\left(310 \mathrm{~m}^{3} / \mathrm{s}\right)$} \\
\hline 0.5 & $69 \%$ & $63 \%$ & $79 \%$ & 3 & 3 \\
\hline
\end{tabular}

\section{CONCLUSIONS}

A study was carried out to investigate whether CEMT Class IV vessels can turn safely at the Quai des Trois Fontaines (Chooz) in France. Real time simulations were carried out with experienced skippers on a 
dedicated inland ship manoeuvring simulator at Flanders Hydraulics Research.

The simulations showed that $80 \mathrm{~m}$ long vessels can safely carry out turning manoeuvres in the existing environment. The manoeuvres can be carried out safely with or without bow thruster and in any hydraulic conditions. This is no longer possible with $85 \mathrm{~m}$ long, let alone $90 \mathrm{~m}$ long vessels.

In order to be able to turn safely with $85 \mathrm{~m}$ and 90 $\mathrm{m}$ long vessels, a local widening of the river on the right bank to $100 \mathrm{~m}$ and $105 \mathrm{~m}$ respectively was proposed. The proposed widening would be over a length of $65 \mathrm{~m}$. Analysis of the simulations indicate that this is sufficient for $85 \mathrm{~m}$ long vessels. However, in order to turn safely with $90 \mathrm{~m}$ long vessels, the local widening to $105 \mathrm{~m}$ needs to be extended over more than $65 \mathrm{~m}$.

A third measure that was proposed, is to use a fixed point (i.e. a dolphin), to which the vessel can attach and around which the vessel can then turn. The simulations show that with a fixed point near the end of the quay, safe manoeuvres are possible with $85 \mathrm{~m}$ and $90 \mathrm{~m}$ long vessels.

The measure of using a fixed point around which the vessel can turn, is cheaper than widening the river locally, but it renders the turning manoeuvre more cumbersome for the crew as lines need to be attached and manipulated correctly. It may be noted that the two measures of widening the river locally and using a fixed point around which the vessel can turn, can also be combined in order to let the skipper choose depending on his feeling and weather conditions.

\section{ACKNOWLEDGEMENTS}

This study was commissioned by Voies Navigables de France (VNF).

The results of the analysis were at several occasions discussed in Givet (France) with representatives of the inland navigation sector and with stakeholders of the Quai des Trois Fontaines, whose valuable input is acknowledged.

\section{REFERENCES}

[1] L'Ardennais (2019). Chooz: l'inexploitable quai des Trois Fontaines. 23 March 2019.

[2] PIANC (2019). Design guidelines for inland waterway dimensions. InCom WG Report $n^{\circ} 141.305$ pp.

[3] Kornacki, J. \& Galor, P. (2007). Analysis of Ships Turn Manoeuvres in Port Water Area. TransNav, Vol. 1 Nr. 1, pp. 95-100.

[4] Kornacki, J. (2010). Analysis of the Influence of Current on the Manoeuvres of the Turning of the Ship on Ports Turning-Basins. TransNav, Vol. 4 Nr. 4, pp. 397-402.

[5] Kornacki, J. (2011). Simulating Method of Ship's Turning-basins Designing. TransNav, Vol. 5 Nr. 2, pp. 241-246.

[6] Kim, S., Lee, Y. \& Park, Y. (2012). A Study on the Size of Turning Basin for Vessels of Arrival \& Departure in the Berths. Jour. Fish. Mar. Sci. Edu., Vol. 24 Nr. 6, pp. 872883.

[7] Eloot, K.; Delefortrie, G.; Vantorre, M. (2012). Inland navigation: assessing the manoeuvring behaviour for real-time simulation purposes, in: MARSIM 2012, 23-27 April, Singapore: abstracts and papers, pp. 1-12.

[8] Verwilligen, J; Delefortrie, G.; Vos, S. ; Vantorre, M. ; Eloot, K. (2015). Validation of mathematical manoeuvring models by full scale measurements, in: MARSIM 2015, 8-11 September, Newcastle upon Tyne, pp. 1-16. 